\title{
BEBERAPA KARAKTER MORFOLOGIS TANAMAN SALAK \\ (Salacca zalacca (Gaert) Voss) DI KAMPUNG BAWOLEU, KECAMATAN TAGULANDANG UTARA, KABUPATEN KEPULAUAN SIAU TAGULANDANG BIARO
}

\author{
SOME MORPHOLOGICAL CHARACTERS OF BARK PLANTS (Salacca zalacca (Gaert) \\ Voss) IN THE VILLAGE BAWOLEU,TAGULANDANG SUBDISTRICT NORTH, DISTRICTS \\ OF THE SIAU TAGULANDANG BIARO ARCHIPELAGO
}

\author{
Andrew R. Pulakiang1), Jeany Sh. Polii-Mandang2), dan Saartje Sompotan2) \\ 1)Mahasiswa Program Studi Agroekoteknologi Fakultas Pertanian Unsrat Manado, 95115 \\ 2)Dosen Jurusan Budidaya Pertanian Fakultas Pertanian Unsrat Manado, 95115
}

\begin{abstract}
The objective of this research was to know the whether thete is a difference the nature of morphological characters local bark and bark butter who grewup in the slums Bawoleu, Tagulandang subdistrict north, Districts of the Siau Tagulandang Biaro Archipelago. This research has been conducted the Village Bawoleu, Tagulandang subdistrict north, Archipelagic Districts Siau Tagulandang Biaro. Research activities implemented starting in November 2016 until Januari 2017. Research conducted using the survey method by means of sampling selected that is Village Bawoleu which is a central plant snake fruit. Samples were taken from the Village Bawoleu and have determined the yard barking plant, many samples of local plants and snake fruit butter set 20 plants were taken by purposive sample, of each plant sample was taken mother longest petiole and fifteenth child leaves. In addition to any plant samples were taken of the bunches and each taken four bunches of fruits to be observed. Based on research results from some plants morphological characters barking in the the Village Bawoleu there are similarities and some differences in morphological characters.
\end{abstract}

Keywords : bark fruit, morphological characters, Tagulandang

\section{ABSTRAK}

Penelitian ini bertujuan untuk mengidentifikasi apakah ada perbedaan sifat karakter morologis salak lokal dan salak mentega yang tumbuh di daerah Kampung Bawoleu, Kecamatan Tagulandang Utara, Kabupaten Kepulauan Siau Tagulandang Biaro. Penelitian ini dilaksanakan di Kampung Bawoleu, Kecamatan Tagulandang Utara, Kabupaten Kepulauan Siau Tagulandang Biaro. Aktifitas penelitian dilaksanakan mulai bulan November 2016 sampai dengan bulan Januari 2017. Penelitian dilaksanakan menggunakan metode survei dengan cara pengambilan sampel secara terpiih yaitu kampung Bawoleu yang merupakan sentral tanaman salak. Sampel diambil dari Kampung Bawoleu dan ditentukan satu pekarangan yang mempunyai tanaman salak, banyaknya sampel tanaman salak lokal dan salak mentega ditetapkan 20 tanaman yang diambil secara purposive sampel, dari setiap tanaman sampel diambil ibu tangkai daun yang paling panjang dan anak daun ke lima belas. Di samping itu pada setiap tanaman sampel diambil satu tandan buah dan masing-masing tandan buah diambil empat buah salak untuk diamati. Berdasarkan hasil penelitian dari beberapa karakter morfologis tanaman salak di Kampung Bawoleu, terdapat persamaan dan beberapa perbedaan karakter morfologis.

Kata kunci : buah salak, karakter morfologis, Tagulandang

Eugenia Volume 23 No. 2 Juni 2017 


\section{PENDAHULUAN}

Salak (Salacca zalacca (Gaert) Voss) merupakan tanaman asli Indonesia. Salak mempunyai nilai ekonomis dan peluang pasar yang cukup luas baik di dalam negeri maupun ekspor (Kusumo, Farid, Sulihanti, dan Sudaryono 1995). Data Badan Pusat Statistik (2012) memperlihatkan bahwa produksi salak di Indonesia berfluktuasi dari tahun 2002-2011, yaitu 768.015 ton (2002), 928.613 ton (2003), 800.975 ton (2004), 937. 930 ton (2005), 861.950 ton (2006), 805.879 ton (2007), 862.465 ton (2008), 829.014 ton (2009), 749.876 ton (2010) dan 815. 227 ton (2011).

Salak merupakan salah satu buah tropis yang saat ini banyak diminati oleh masyarakat. Keunggulan buah salak yakni memiliki kandungan gizi yang cukup tinggi, dari setiap $100 \mathrm{~g}$ buah mengandung 77 kalori, 0,5 g protein, $20,9 \mathrm{~g}$ karbohidrat, $28 \mathrm{mg}$ kalsium, $18 \mathrm{mg}$ fosfor, $4,2 \mathrm{mg}$ besi, $0,04 \mathrm{mg}$, vitamin B1 dan vitamin C $2 \mathrm{mg}$ (Anonim, 1995).

Kampung Bawoleu Kecamatan Tagulandang Utara merupakan salah satu wilayah di Kepulauan Siau Tagulandang Biaro, dengan Ibukota Bawoleu terletak antara 2021'40"LU-

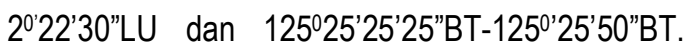
Luas wilayah Kecamatan Tagulandang Utara sebesar $17,92 \mathrm{~km}^{2}$ atau $28,29 \%$ dari total luas wilayah Kecamatan Tagulandang Utara. Pulau Tagulandang sebagai salah satu pusat perkebunan salak mempunyai potensi yang cukup besar untuk menghasilkan varietas-varietas unggul yang lebih bernilai ekonomis dan kompetitif (Darmadi, 2001). Berdasarkan survei pada lahan petani salak di Pulau Tagulandang khususnya Kecamatan Tagulandang Utara memiliki $400 \mathrm{Ha}$ tanaman salak dari 1752 Ha luas Kecamatan Tagulandang Utara. Produksi buah salak hanya untuk Kecamatan Tagulandang Utara mencapai 6000 ton per tahun. Perkebunan salak di Tagulandang Utara dikelolah oleh masyarakat pada lima kampung, yaitu Kampung Bawoleu, Bawo, Wo, Lumbo dan Minanga (Statistik Kantor Kecamatan, 2012). Di Kecamatan Tagulandang Utara terdapat dua jenis salak yaitu salak mentega dan salak lokal, kedua jenis salak ini penanamannya menyebar luas di Kampung Bawoleu.

Di Indonesia terdapat beberapa varietas salak yang dibudidayakan petani, oleh karena itu pengkajian mengenai karakter morfologis perlu diketahui. Informasi mengenai keragaman sangat diperlukan dalam program pemuliaan tanaman karena dengan semakin tersedianya informasi tersebut, semakin mudah dalam menentukan kedudukan atau kekerabatan antar varietas yang dapat dijadikan sebagai dasar seleksi tanaman (Puslitbanbun, 2007).

Penelitian Karakter morfologis bertujuan untuk mendapatkan data sifat dasar sehingga dapat dibedakan fenotip dari setiap aksesi dengan cepat dan mudah, dengan menduga seberapa besar keragaman genetik yang dimiliki (Bermawie, 2005). Karakteristik morfologis tanaman salak dapat dilihat berdasarkan ciri vegetatif maupun ciri generatifnya yang berguna untuk mendapatkan deskripsi dan klasifikasi tanaman salak sehingga dapat mempermudah dalam menentukan varietas tanaman salak. Pada masa mendatang masih ada kemungkinan ditemukan varietas baru, mengingat terjadinya penyerbukan silang (Santoso 1990).

Pengamatan morfologis berguna untuk mengetahui pengembangan budidaya tanaman salak melalui pemuliaan. Untuk itu perlu dilakukan identifikasi morfologis tanaman salak. Dari hasil penelitian Fatimah (2013) terhadap 11 kultivar salak, sifat morfologis yang diamati terdiri dari 37 karakter dan terdapat 12 karakter morfologis yang sama, 9 karakter morfologis terdapat sebagian persamaan dan 16 karakter morfologi yang memiliki perbedaan. Informasi mengenai karakteristik salak Tagulandang sampai saat ini belum pernah ada sebelumnya. Informasi tersebut penting untuk diketahui guna pengembangan budidaya tanaman salak di Kabupaten Kepulauan Siau Tagulandang Biaro.

Berdasarkan hal tersebut, maka penulis terdorong untuk melakukan penelitian mengenai beberapa karakteristik morfologis tanaman salak di Kampung Bawoleu, Kecamatan Tagulandang Utara yang merupakan sentra perkebunan salak di Kabupaten Kepulauan Siau Tagulandang Biaro. Hasil akhir dari penelitian ini diharapkan bisa 
digunakan sebagai bahan acuan maupun informasi bagi pengembangan tanaman salak dimasa yang akan datang, serta untuk menghasilkan tanaman salak yang berkualitas sebagai nilai jual ekonomi.

Penelitian ini bertujuan untuk mengidentifikasi apakah ada perbedaan sifat karakter morfologis salak lokal dan salak mentega yang tumbuh di daerah Kampung Bawoleu, Kecamatan Tagulandang Utara, Kabupaten Kepulauan Siau Tagulandang Biaro. Manfaat penelitian ini diharapkan bermanfaat bagi pengembangan Tanaman Salak di Kabupaten Kepulauan Siau Tagulandang Biaro.

\section{METODE PENELITIAN}

Penelitian dilaksanakan di kebun petani salak Kampung Bawoleu, Kecamatan Tagulandang Utara, Kabupaten Kepulauan Siau Tagulandang Biaro. Aktifitas penelitian dilaksanakan mulai bulan November 2016 sampai dengan bulan Januari 2017.

Alat dan bahan yang akan digunakan dalam penelitian ini adalah tanaman salak mentega dan salak lokal Kampung Bawoleu, kuesioner, data sekunder, kamera, gunting, parang, gergaji, tali, papan triplek, pilox, meteran, dan alat tulis menulis.

Penelitian dilaksanakan menggunakan metode survei dengan cara pengambilan sampel secara terpilih yaitu Kampung Bawoleu yang merupakan sentra tanaman salak. Sampel diambil dari Kampung Bawoleu dan ditentukan satu pekarangan yang terdapat tanaman salak. Banyaknya sampel tanaman salak lokal dan salak mentega ditetapkan 20 tanaman yang diambil secara purposive sampel, dari setiap tanaman sampel diambil ibu tangkai daun yang paling panjang dan anak daun ke lima belas. Di samping itu pada setiap tanaman sampel diambil satu tandan buah dan masing-masing tandan buah diambil empat buah salak untuk diamati.

Karakter yang diamati meliputi : 1) Morfologi batang : tinggi tanaman dan lingkar batang; 2) Morfologi daun : panjang pelepah, jumlah anak daun, panjang ibu tangkai daun dan panjang helai anak daun; 3) Morfologi buah : warna kulit buah, bentuk buah, jumlah buah per tandan, dan jumlah tandan perpohon.

\section{Prosedur Penelitian}

Pelaksanaan penelitian dimulai dengan penentuan lokasi, maka lokasi yang diperoleh adalah Kampung Bawoleu, Lindongan IV. Kemudian dilakukan pengambilan sampel metode purposive sampling dan melakukan wawancara kepada petani.

\section{Pengamatan dan pengukuran}

Pengamatan dan pengukuran terdiri atas 10 karakter yaitu : 1) Pengukuran tinggi tanaman : Pengukuran diukur dari batang paling bawah sampai tinggi pucuk; 2) Panjang pelepah : Pengamatan pada bagian ini yaitu diambil dari pelepah yang paling panjang; 3) Panjang ibu tangkai daun : Pengamatan pada bagian ini dipilih pada ibu daun yang paling panjang; 4) Panjang helai anak daun : Pengamatan pada bagian ini dipilih pada helai anak daun ke lima belas; 5) Jumlah anak daun : Pengamatan pada bagian ini diambil pada jumlah daun yang paling banyak kemudian dihitung jumlahnya; 6) Lingkar batang : Pengamatan ini bertujuan untuk mengetahui seberapa besar tumbuh dan berkembang; 7) Jumlah tandan buah perpohon : Pengamatan pada bagian ini dilihat dari tandan buah yang sudah muncul; 8) Jumlah buah pertandan : Jumlah buah dihitung dari banyaknya buah yang sudah muncul; 9) Warna kulit buah matang : Warna kulit di lihat dari ciri warna kulit salak yang sudah matang; 10) Bentuk buah : Pengamatan pada bagian ini dilihat ketika buah siap panen.

\section{HASIL DAN PEMBAHASAN}

\section{Karakter Tinggi Tanaman}

Data hasil pengamatan pada karakter morfologi tinggi tanaman salak di Kampung Bawoleu dapat dilihat pada Tabel 1. 
Tabel 1. Karakter Tinggi Tanaman Salak

(Table 1. High Character of Bark Plants)

\begin{tabular}{ccc}
\hline \multirow{2}{*}{ No Sampel } & \multicolumn{3}{c}{ Tinggi Tanaman $(\mathrm{m})$} & Salak Lokal \\
\cline { 2 - 3 } & Salak Mentega & 3,9 \\
2 & 3,5 & 3,6 \\
3 & 4,2 & 3,9 \\
4 & 3,8 & 3,7 \\
5 & 4,2 & 3,7 \\
6 & 4,1 & 3,5 \\
7 & 4,0 & 3,7 \\
8 & 3,7 & 3,8 \\
9 & 3,8 & 4,0 \\
10 & 4,1 & 4,0 \\
11 & 4,0 & 4,0 \\
12 & 3,8 & 3,8 \\
13 & 3,7 & 4,0 \\
14 & 3,8 & 3,9 \\
15 & 3,9 & 3,9 \\
16 & 4,1 & 3,8 \\
17 & 3,7 & 4,0 \\
18 & 4,3 & 3,7 \\
19 & 4,1 & 3,9 \\
20 & 4,2 & 3,6 \\
\hline Rata-rata & 4,0 & 3,82 \\
\hline
\end{tabular}

Tabel 1 menunjukkan dari kedua jenis salak Tagulandang (salak mentega dan salak lokal) yang digunakan dalam penelitian ini memiliki karakter tinggi tanaman yang tidak jauh berbeda yaitu salak mentega berkisar 3,5-4,3 m dengan ratarata 3,95 $\mathrm{m}$ dan salak lokal berkisar antara 3,5 - 4,0 $\mathrm{m}$, dengan rata-rata $3,82 \mathrm{~m}$.

Tinggi salak mentega dan salak lokal lebih pendek dibanding salak Sumatera Utara (Salacca sumatrana becc) yang ada di daerah Kabupaten Tapanuli Selatan seperti pada penelitian Harahap, Bayu, Siregar (2013), yang memiliki tinggi tanaman antara 6,8 m-7,6 m. Hal ini diduga karena kesuburan tanah yang berbeda, cara budidaya yang berbeda, iklim yang berbeda atau sifat genetik yang berbeda.

\section{Karakter Panjang Pelepah}

Data hasil pengamatan karakter morfologi panjang pelepah salak di Kampung Bawoleu dapat dilihat pada Tabel 2.
Tabel 2 menunjukkan karakter panjang pelepah salak mentega berkisar $64-89 \mathrm{~cm}$ dengan rata-rata $74,25 \mathrm{~cm}$ lebih panjang dibandingkan dengan salak lokal yang berkisar $52-80 \mathrm{~cm}$ dengan rata-rata $69,05 \mathrm{~cm}$.

\section{Karakter Panjang Ibu Tangkai Daun}

Data hasil pengamatan karakter morfologi panjang ibu tangkai daun di Kampung Bawoleu dapat dilihat pada Tabel 3 .

Dari Tabel 3 diperoleh rata-rata panjang tangkai daun salak mentega 2,8 $\mathrm{m}$ dengan kisaran antara 2,5 - 3,4 $\mathrm{m}$, sedangkan rata-rata panjang tangkai daun salak lokal 2,7 $\mathrm{m}$ dengan kisaran antara 2,3 - 3,1 m. Dari data tersebut terlihat bahwa panjang tangkai daun kedua tanaman salak relatif tidak berbeda. Namun panjang tangkai salak mentega dan salak lokal lebih pendek dibanding dengan salak Sumatera (Salacca sumatrana Becc) yang memiliki panjang tangkai mencapai 4,3 - 5,6 m (Harahap, Bayu, Siregar 2013). 
Tabel 2. Data Karakter Panjang Pelepah Daun Salak

(Table 2. Long Character of Bark Leaf)

\begin{tabular}{|c|c|c|}
\hline \multirow{2}{*}{ No Sampel } & \multicolumn{2}{|c|}{ Panjang Pelepah (cm) } \\
\hline & Salak Mentega & Salak Lokal \\
\hline 1 & 68 & 73 \\
\hline 2 & 78 & 72 \\
\hline 3 & 66 & 80 \\
\hline 4 & 89 & 60 \\
\hline 5 & 85 & 61 \\
\hline 6 & 79 & 52 \\
\hline 7 & 65 & 67 \\
\hline 8 & 75 & 73 \\
\hline 9 & 64 & 78 \\
\hline 10 & 72 & 79 \\
\hline 11 & 74 & 59 \\
\hline 12 & 80 & 73 \\
\hline 13 & 72 & 78 \\
\hline 14 & 84 & 62 \\
\hline 15 & 78 & 77 \\
\hline 16 & 73 & 75 \\
\hline 17 & 71 & 72 \\
\hline 18 & 72 & 59 \\
\hline 19 & 74 & 63 \\
\hline 20 & 66 & 68 \\
\hline Rata-Rata & 74,25 & 69,05 \\
\hline
\end{tabular}

Tabel 3. Karakter Panjang lbu Tangkai Daun Salak.

(Table 3. The Long Character of The Mother of The Bark)

\begin{tabular}{ccc}
\hline \multirow{2}{*}{ No Sampel } & \multicolumn{2}{c}{ Panjang lbu Tangkai Daun $(\mathrm{m})$} \\
\cline { 2 - 3 } & Salak Mentega & Salak Lokal \\
\hline 1 & 2,5 & 2,8 \\
3 & 3,0 & 2,5 \\
4 & 2,7 & 2,6 \\
5 & 2,7 & 2,4 \\
6 & 2,6 & 2,6 \\
7 & 2,7 & 2,6 \\
8 & 2,5 & 2,5 \\
9 & 2,7 & 2,7 \\
10 & 2,9 & 2,7 \\
11 & 2,8 & 2,9 \\
12 & 2,6 & 3,1 \\
13 & 2,7 & 2,7 \\
14 & 2,7 & 2,9 \\
15 & 2,9 & 2,8 \\
16 & 3,0 & 2,8 \\
17 & 2,8 & 2,8 \\
18 & 3,1 & 2,9 \\
19 & 3,1 & 2,5 \\
20 & 3,3 & 2,9 \\
Rata- Rata & 3,4 & 2,3 \\
\hline
\end{tabular}




\section{Karakter Panjang Helai Anak Daun}

Data hasil pengamatan karakter morfologi panjang helai anak daun dapat dilihat pada Tabel 4.

Tabel 4 menunjukkan panjang helai anak daun tanaman salak mentega dan salak lokal memiliki panjang helai anak daun yang relatif sama.

Pada salak pondoh hasil penelitian Suskendriyati, Wijayati, Hidayah, Cahyuningdari (2000) mendapatkan panjang helai anak daun salak pondoh berkisar $55-78 \mathrm{~cm}$, ternyata jelas lebih panjang dari salak mentega dan salak lokal yang ada dikampung bawoleu. Hal ini diduga karena kesuburan tanah yang berbeda, cara budidaya yang berbeda, iklim yang berbeda atau sifat genetik yang berbeda.

\section{Karakter Jumlah Anak Daun}

Data hasil pengamatan pada karakter morfologi jumlah anak daun dapat dilihat pada Tabel 5.

Tabel 5 menunjukkan rata-rata jumlah anak daun salak mentega yaitu 61,7 dengan kisaran 58 - 70 helai anak daun sedangkan salak lokal rata-rata yaitu 55,4 dengan kisaran $50-60$ helai anak daun.

Penelitian yang dilakukan Herawati, Chasanah, Kamsinah (2012) pada salak lokal Banyumas (Salacca zalacca (Gaert) Voss) mendapatkan jumlah anak daun pada salak lokal Banyumas berkisar 58 - 64 helai anak daun. Ternyata antara salak Kampung Bawoleu dan salak lokal Banyumas hampir memiliki kesamaan dalam karakter jumlah helai anak daun.

Tabel 4. Karakter Panjang Helai Anak Daun Salak.

(Table 4. The Long Character of The Strands of The Child of Bark)

\begin{tabular}{ccc}
\hline \multirow{2}{*}{ No Sampel } & \multicolumn{2}{c}{ Panjang Helai Anak Daun $(\mathrm{cm})$} \\
\cline { 2 - 3 } & Salak Mentega & Salak Lokal \\
\hline 1 & 52 & 51 \\
3 & 47 & 41 \\
4 & 53 & 45 \\
5 & 58 & 42 \\
6 & 55 & 55 \\
7 & 49 & 49 \\
8 & 46 & 49 \\
9 & 47 & 63 \\
10 & 50 & 67 \\
11 & 54 & 65 \\
12 & 57 & 54 \\
13 & 58 & 61 \\
14 & 63 & 66 \\
15 & 55 & 63 \\
16 & 52 & 54 \\
17 & 51 & 56 \\
18 & 55 & 47 \\
19 & 53 & 42 \\
20 & 55 & 42 \\
Rata - Rata & 59 & 49 \\
\hline
\end{tabular}


Tabel 5. Karakter Jumlah Anak Daun Salak.

(Table 5. Character of The Number of Children of Bark)

\begin{tabular}{ccc}
\hline \multirow{2}{*}{ No. Sampel } & \multicolumn{2}{c}{ Jumlah Anak Daun } \\
\cline { 2 - 3 } & Salak Mentega & Salak Lokal \\
\hline 1 & 60 & 54 \\
2 & 58 & 56 \\
4 & 60 & 56 \\
5 & 70 & 54 \\
6 & 60 & 56 \\
7 & 58 & 50 \\
8 & 60 & 54 \\
9 & 62 & 56 \\
10 & 68 & 58 \\
11 & 66 & 56 \\
12 & 58 & 54 \\
13 & 62 & 54 \\
14 & 68 & 56 \\
15 & 58 & 56 \\
16 & 60 & 60 \\
17 & 58 & 60 \\
18 & 62 & 52 \\
20 & 60 & 52 \\
Rata- Rata & 66 & 56 \\
\hline
\end{tabular}

\section{Karakter Lingkar Batang}

Data hasil pengamatan karakter morfologi lingkar batang tanaman salak di Kampung Bawoleu dapat dilihat pada Tabel 6 .

Tabel 6 menunjukkan rata-rata lingkar batang tanaman salak mentega yaitu $34,5 \mathrm{~cm}$ dengan kisaran $28-46 \mathrm{~cm}$ sedangkan salak lokal rata-rata $33,65 \mathrm{~cm}$ dengan kisaran $29-45 \mathrm{~cm}$. Jadi kedua salak tersebut memiliki lingkar batang yang relatif sama.

\section{Karakter Jumlah Tandan Buah Perpohon}

Data hasil pengamatan karakter morfologi jumlah tandan buah perpohon di Kampung Bawoleu dapat dilihat pada Tabel 7.

Berdasarkan Tabel 7 disimpulkan bahwa tanaman salak mentega dan salak lokal dalam karakter jumlah tandan buah perpohon hampir tidak memiliki perbedaan. Hasil karakter tersebut hampir sama dengan hasil penelitian yang dilakukan Herawati, Chasanah, Kamsinah (2012) mendapatkan jumlah tandan buah perpohon pada salak lokal Banyumas (Salacca zalacca (Gaert) Voss) berkisar 3 - 5 tandan buah perpohon. Ternyata pada karak- ter jumlah tandan buah perpohon antara salak Kampung Bawoleu dan salak lokal Banyumas relatif tidak memiliki perbedaan.

\section{Karakter Jumlah Buah per Tandan}

Data hasil pengamatan karakter morfologi jumlah buah per tandan di Kampung Bawoleu dapat dilihat pada Tabel 8.

Sesuai wawancara dengan petani salak di Kampung Bawoleu dikatakan bahwa salak mentega lebih banyak berbuah dibanding dengan salak lokal, itu terlihat pada Tabel 8. Salak mentega berkisar 9 - 24 buah dengan rata-rata 17 buah per tandan, sedangkan salak lokal berkisar 7 - 19 buah per tandan dengan rata-rata 13 buah per tandan.

Namun pada tanaman salak pondoh seperti hasil penelitian Suskendriyati, Wijayati, Hidayah, Chayuningdari (2000) mendapatkan jumlah buah pertandan berkisar $4-35$ buah per tandan, jauh lebih banyak dibandingkan dengan salak yang ada di Kampung Bawoleu. Hal ini diduga sifat genetik yang berbeda. 
Tabel 6. Karater Lingkar Batang Tanaman Salak.

(Table 6. Character of The Stem of The Bark Tree)

\begin{tabular}{ccc}
\hline \multirow{2}{*}{ No Sampel } & \multicolumn{2}{c}{ Lingkar Batang $(\mathrm{cm})$} \\
\cline { 2 - 3 } 1 & Salak Mentega & Salak Lokal \\
2 & 38 & 38 \\
3 & 36 & 35 \\
4 & 30 & 36 \\
5 & 43 & 34 \\
6 & 30 & 33 \\
7 & 32 & 31 \\
8 & 44 & 32 \\
9 & 36 & 33 \\
10 & 34 & 31 \\
11 & 36 & 35 \\
12 & 33 & 31 \\
13 & 34 & 33 \\
14 & 28 & 35 \\
15 & 33 & 31 \\
16 & 30 & 35 \\
17 & 33 & 30 \\
18 & 30 & 29 \\
19 & 30 & 36 \\
20 & 34 & 45 \\
\hline Rata - Rata & 46 & 33,65 \\
\hline
\end{tabular}

Tabel 7. Karakter Jumlah Tandan Buah Perpohon.

(Table 7. Character Number of Fruit Bunches of The Trees)

\begin{tabular}{ccc}
\hline \multirow{2}{*}{ No Sampel } & \multicolumn{2}{c}{ Jumlah Tandan Buah Perpohon } \\
\cline { 2 - 3 } & Salak Mentega & Salak Lokal \\
\hline 1 & 4 & 3 \\
3 & 3 & 3 \\
4 & 3 & 3 \\
5 & 4 & 4 \\
6 & 3 & 4 \\
7 & 4 & 4 \\
8 & 6 & 2 \\
9 & 3 & 5 \\
10 & 6 & 6 \\
11 & 4 & 6 \\
12 & 6 & 4 \\
13 & 4 & 5 \\
14 & 5 & 6 \\
15 & 5 & 5 \\
16 & 4 & 3 \\
17 & 6 & 2 \\
18 & 3 & 3 \\
19 & 4 & 5 \\
20 & 5 & 2 \\
\hline Rata & 6 & 3,95 \\
\hline
\end{tabular}


Tabel 8. Karakter Jumlah Buah Pertandan

(Table 8. Character Number of Fruit Bunches)

\begin{tabular}{ccc}
\hline \multirow{2}{*}{ No. Sampel } & \multicolumn{2}{c}{ Jumlah Buah Pertandan } \\
\cline { 2 - 3 } & Salak Mentega & Salak Lokal \\
\hline 1 & 9 & 13 \\
3 & 17 & 11 \\
4 & 16 & 13 \\
5 & 18 & 15 \\
6 & 16 & 9 \\
7 & 18 & 7 \\
8 & 16 & 18 \\
9 & 17 & 18 \\
10 & 16 & 14 \\
11 & 15 & 9 \\
12 & 16 & 10 \\
13 & 20 & 8 \\
14 & 18 & 14 \\
15 & 17 & 18 \\
16 & 12 & 11 \\
17 & 18 & 7 \\
18 & 16 & 17 \\
19 & 17 & 11 \\
20 & 24 & 13 \\
Rata - Rata & 21 & 19 \\
\hline
\end{tabular}

\section{Karakter Warna Kulit Buah Matang}

Hasil dari identifikasi karakter morfologis

salak di Kampung Bawoleu yaitu pada karakter warna kulit buah matang terdapat perbedaan, salak mentega berwarna kuning kecoklatan sedangkan salak lokal berwana coklat sampai coklat kehitaman. Hal ini diduga karena sifat genetik kedua jenis salak tersebut yang berbeda.

Pada penelitian yang dilakukan Suskendriyati, Wijayati, Hidayah, Cahyuningdari (2000) mendapatkan warna kulit buah matang pada salak pondoh (Salacca zalacca (Gaert) Voss) memiliki warna dari coklat kehitaman, coklat kemerahan, hitam kemerahan, merah kekuningan, sampai kuning cerah. Hal ini diduga karena sifat genetik yang berbeda.

\section{Karakter Bentuk Buah Salak}

Morfologi buah salak pada umumnya bervariasi, tergantung jenis atau varietasnya. Pada penelitian yang dilakukan di Kampung Bawoleu bentuk buah salak lokal dan salak mentega bulat sampai lonjong, dengan ujung meruncing dan pantat bulat.

Perbedaan yang dapat dilihat secara visual yang lain adalah ketika buah salak sudah matang di pohon, salak mentega lebih cepat jatuh dari tandan dan kulit cepat pecah, hal ini diduga karena sifat genetik berbeda, kadar air yang berbeda antara salak lokal dan salak mentega.

\section{KESIMPULAN DAN SARAN}

\section{Kesimpulan}

Terdapat persamaan dan perbedaan karakter morfologis tanaman salak di Kampung Bawoleu, Kecamatan Tagulandang Utara, Kabupaten Kepulauan Siau Tagulandang Biaro.

Persamaan karakter morfologis terdapat pada: karakter tinggi tanaman, panjang pelepah, panjang ibu tangkai daun, panjang helai anak daun, jumlah anak daun, lingkar batang, jumlah tandan 
buah perpohon dan bentuk buah dari kedua jenis salak relatif tidak berbeda.

Perbedaan karakter morfologis terdapat pada: 1) Karakter jumlah buah pertandan : salak mentega lebih banyak berbuah dibandingkan dengan salak lokal; 2) Karakter warna kulit buah matang : salak mentega memiliki warna kuning kecoklatan sedangkan salak lokal memiliki warna coklat sampai coklat kehitaman; 3) perbedaan visual yang lain dapat dilihat ketika buah salak sudah matang. Salak mentega lebih cepat jatuh dari tandan dan kulit cepat pecah dibandingkan dengan salak lokal.

\section{Saran}

Diharapkan adanya kajian mendalam tentang kekerabatan salak mentega dan salak lokal yang ada di Kampung Bawoleu, Kecamatan Tagulandang Utara, Kabupaten Kepulauan Siau Tagulandang Biaro.

\section{DAFTAR PUSTAKA}

Anonim. 1995. Direktorat Gizi. Departemen Kesehatan Republik Indonesia. Dalam Teknik Produksi Salak Pusat Penelitian dan Pengembangan Hortikultura. Badan Litbang Pertanian Jakarta. $67 \mathrm{HIm}$.

Badan Pusat Statistik. 2012. Produksi buah-buahan di Indonesia. http://www.bps.go.id/ tab_sub/view.php?kat=3\&tabel=1\&daftar= 1\&id subyek=55\&notab=3. [16 Juni 2012]

Bermawie, N. 2005. Karakterisasi Plasma Nutfah Tanaman. Buku Pedoman Pengelolaan Plasma Nutfah Perkebunan. Pusat Penelitian dan Pengembangan Perkebunan, Bogor : 38-52.

Darmadi, 2001. Tingkat kematangan Salak. Skripsi IPB. Bogor.
H. Suskendriyati, Arta Wijayati, Nur Hidayah, dan Dewi Chayuningdari. 2000. Studi Morfologi dan Hubungan Kekerabatan Varietas Salak Pondoh di Dataran Tinggi Sleman. FMIPA. Universitas Surakarta. Biodiversitas Vol. 1, Nomor 2, Juli 2000, Hal 59-64.

Hilda Mei Yeni Harahap, Eva Sartini Bayu, dan Luthfi A.M. Siregar. 2013. Identifikasi Karakter Morfologis Salak Sumatera Utara (Salacca sumatrana Becc.) di Beberapa Daerah Kabupaten Tapanuli Selatan. Agroekoteknologi. Universitas Sumatera Utara. Agroekoteknologi vol 1. Nomor 3 Juni 2013.

Kusumo, S., A.B. Farid, S. Sulihanti, K. Yusri, Suhardjo dan T. Sudaryono. 1995. Teknologi Produksi Salak Jakarta: Pusat Penelitian dan Pengembangan Hortikultural Badan Peneltian dan Pengembangan Departemen Pertanian.

Puslitbanbun. 2007. Petunjuk pelaksanaan Pengelolaan Plasma Nutfah Tanaman Perkebunan. Pusat penelitian dan Pengembangan perkebunan. Bogor.

Santoso, H.B. 1990. Salak Pondoh. Yogyakarta: Penerbit Kanisius.

Fatimah, S. 2013. Analsis Morfologi dan Hubungan Kekerabatan Sebelas Jenis Tanaman Salak. Universitas Trunoyono Madura. Agrovigor Volume 6 No. 1 Maret 2013.

Wiwik Herawati, Titi Chasanah, dan Kamsinah. 2012. Karakteristik Salak Lokal Banyumas (Salacca zalacca (Gaert.) Voss). Fakultas Biologi. Universitas Jendral Soedirman. Prosiding Seminar Nasional. November 2012. 